\title{
RELEVANCE OF MAXILLOFACIAL ANATOMY IN ENDODONTICS: A REVIEW
}

\section{PREGLED ZNAČAJA MAKSILOFACIJALNE ANATOMIJE U ENDODONCIJI}

\author{
Krishnaraj Somayaji S. ${ }^{1}$, Mohandas Rao KG ${ }^{2}$ \\ ${ }^{1}$ MANIPAL UNIVERSITY, DEPARTMENT OF CONSERVATIVE DENTISTRY AND ENDODONTICS, MANIPAL COLLEGE OF DENTAL \\ SCIENCES, MANIPAL, INDIA \\ ${ }^{2}$ MANIPAL UNIVERSITY, DEPARTMENT OF ANATOMY, MELAKA MEDICAL COLLEGE, MANIPAL, INDIA \\ ${ }^{1}$ UNIVERZITET U MANIPALU, ODELJENJE ZA KONZERVATIVNU STOMATOLOGIJU I ENDODONCIJU, \\ STOMATOLOŠKI FAKULTET MANIPAL, INDIJA \\ ${ }^{2}$ UNIVERZITET U MANIPALU, ODELJENJE ZA ANATOMIJU, MEDICINSKI FAKULTET MELAKA, MANIPAL, INDIJA
}

\section{Abstract}

A thorough anatomical knowledge is very essential for any surgical procedure. The idea of location of various structures in the body prepares the clinician for a better approach to establishing diagnosis and various surgical procedures. Unfortunately, anatomical variation. can lead to hazards in diagnosis and treatment. Referred pain and pain of unknown origin or temporomandibular joint pain sometimes may lead to confusion or misinterpretation in proper diagnosis. Abnormal course and distribution of nerves and vessels may sometimes become course and distribution of nerves and vessels may sometimes becon of the two sides supplying the teeth or some of the nerves may be duplicated in the whole or part of their course. Such conditions may lead to problems in anesthetizing teeth or unexpected pain sensations expressed by the patient during the endodontic treatments. Anatomical relation of maxillary air sinus to the upper teeth and the possible clinical complications during the treatment is also important. Relation of neurovascular bundle to the sinus may sometimes vary. Lack of knowledge of normal anatomy may lead to misinterpretation of tests leading to wrong diagnosis and management.

Concept of anatomical variations is of utmost importance to prevent complications of anesthetic procedures.

Key words: maxillofacial surgery, endodontics, dental anesthesia, man dibular nerve, maxillary nerve, maxillary sinus, temperomandibular joint

\section{Introduction}

A thorough knowledge of anatomical structures is essential for dental surgeons during various surgical procedures. In the general practice, local anesthesia is often achieved by injection of a local anesthetic solution into the tissue sur-

Address for correspondence:

Krishnaraj Somayaji S, DDS

Department of Conservative Dentistry and Endodontics

Manipal College of Dental Sciences

Manipal, 576104

Karnataka, India.

Phone: +919901726764

E-mail: sksomayaji@gmail.com
Sažetak

Detaljno znanje anatomije ključno je prilikom bilo koje hirurške intervencije. Poznavanje lokacije razlicitih struktura u telu preduslov je adekvatne dijagnoze i izboru hirurške metode. Nažalost, individualne varijacije $u$ anatomskoj građi često predstavljaju rizik prilikom dijagnoze $i$ tretmana. Iradirajući bol, bol nepoznatog porekla ili bol u TMZ mogu dovesti do konfuzije i pogrešnog tumačenja oboljenja. Abnormalni pravac pružanja i distribucija nerava i krvnih sudova ponekad predstavlja veliki problem. Moguće je i obostrano preklapanje nerava koji inervišu zube ili neki nervi mogu biti delom ili čitavim prevcem pružanja duplicirani. Ovakvi uslovi mogu da izazovu problemi u toku anesteziranja zuba ili neočekivani osećaj bola za vreme endodontskog lečenja. Anatomski odnos maksiranog sinusa sa gornjim zubima i moguće kliničke komplikacije za vreme lečenja takođe igraju veliku ulogu. Odnos neurovaskularnog snopa i sinusa ponekad može da varira. Nepoznavanje anatomije može dovesti do pogrešne interpretacije testova koji dovode do pogrešne dijagnoze i lečenja.

Koncept anatomskih varijacija je od najvećeg značaja za prevenciju komplikacija u toku anestezioloških procedura.

Ključne reči: maksilofacijalna hirurgija, endodoncija, dentalna anestezija, mandibularni nerv, maksilarni nerv, maksilarni sinus, temporomandibularni zglob

\section{Uvod}

Detaljno poznavanje anatomskih struktura od vitalnog je značaja za oralne hirurge u toku različitih hirurških procedura. Lokalna anestezija se najčešće postiže ubrizgavanjem rastvora lokalnog anestetika u tkivo oko nerva koji 
rounding the nerve innervating the area to be treated. In many cases, the failure in anesthesia is due to anatomical abnormalities or variations ${ }^{1}$. The clinician must be able to assess whether it is operator's error or anatomical anomaly which is responsible for inadequate pain management. Therefore, it is relevant for dentists to discuss the normal and abnormal anatomy of the mandibular and maxillary nerves in relation to other anatomical structures like temporomandibular joint and maxillary sinus.

\section{Mandibular nerve}

Inferior alveolar nerve (IAN) is a branch of posterior division of mandibular nerve which traverses the mandibular canal and innervates the teeth of lower jaw. The course of the IAN vary $^{2}$. The variations of mandibular canal can be divided into four categories: 1. High mandibular canals (within $2 \mathrm{~mm}$ of the apices of the molars), 2. Intermediate mandibular canals, 3 . Low mandibular canals, and 4. Duplication or division of the canal, apparent partial or complete absence of the canal or lack of symmetry ${ }^{3}$. Mostly, the mandibular canals are bilaterally symmetrical with only one major canal on each side. Communication patterns between the mandibular nerve branches are a possible cause of incomplete anesthesia during dental practice $^{4}$. IAN sending fibers to the lingual nerve (LN) through a communicating branch has been considered clinically relevant for the supplementary innervation of the lower molars ${ }^{5}$.

During administration of local anesthetics, intravascular puncture of maxillary artery which is passing through a communicating loop from the auriculotemporal to the inferior alveolar nerve can cause a hematoma which may compress nerves in the infratemporal fossa, producing sensory alterations ${ }^{6}$. Course of maxillary artery through the inferior alveolar nerve, splitting it into superficial and deep divisions may lead to its entrapment and may cause numbness or headache, can even interfere with injection of local anesthetics ${ }^{7}$. Maxillary artery is variably related to the mandibular foramen ${ }^{8}$. Therefore, the use of panoramic radiographs should be considered in locating the mandibular foramen rather than relying on bony landmarks $^{9}$. Branches of the mandibular division or of its inferior alveolar or buccal branch may inerviše ciljano područije. U najvećem broju slučajeva razlog neuspeha anestezije leži u anatomskim abnormalnostima i varijacijama ${ }^{1 .}$ Kliničar mora biti sposoban da proceni da li se radi o grešci lekara ili anatomskoj anomaliji. Stoga je razmatranje normalne, kao i abnormalne anatomije mandibularnih i maksilarnih nerava u odnosu na druge anatomske strukture, poput TMZ i makslarnoig sinusa, od velike važnosti za stomatologe.

\section{Mandibularni nerv}

Donji alveolarni nerv (DAN) je ogranak posteriornog podeoka mandibularnog nerva koji dijagonalno seče mandibularni kanal i inervise zube donje vilice. Pravac pružanja DAN, međutim, može da varira ${ }^{2}$. U pogledu varijacije mandibularnog kanala razlikujemo 4 kategorije: 1. visoki mandibularni kanali (do $2 \mathrm{~mm}$ od vrhova molara), 2. srednji mandibularni kanali; 3. niski mandibularni kanali, 4. duplikacija ili podela kanala, očigledno delimično ili potpuno odsustvo kanala ili simetrije ${ }^{3}$. Mandibularni kanali su uglavnom bilateralno simetrični sa samo jednim glavnim kanalom sa svake strane. Način komunikacije između ogranaka madibularnog nerva moguć je uzrok nepotpune anestezije ${ }^{4}$. Za dodatnu inervaciju donjih molara klinički je relevantan i komunikantni ogranak nerva koji povezuje donji alveoralni nerv i lingvalni nerv 5 .

Povreda a. maxilaris, koja se proteže kroz komunikantnu petlju od aurikulotemporalnog do donjeg alveolarnog nerva, prilikom davanja lokalne anestezije može da dovede do pojave hematoma koji pritiska nerve u infratemporalnoj jami i izaziva senzitivne promene ${ }^{6}$. A. maxilaris svojim pravcem pružanja deli mandibularni kanal na površinski i duboki deo, što može dovesti do konstrikcije donjeg alveolarnog nerva i izazvati utrnulost, glavobolju i poteškoće prilikom ubrizgavanja lokalnog anestetika ${ }^{7}$. Kako ova arterija može biti različito pozicionirana u odnosu na mandiblarni otvor ${ }^{8}$, u obzir treba uzeti upotrebu panoramskog snimka, u cilju lociranja mandibularnog otvora umesto oslanjanja na koštane orijentire ${ }^{9}$. Ogranci mandibularnog nerva, tj. donji alveolarni i bukalni ogranak, mogu da uđu u mandibulu kroz retromolarnu oblast inervišući prve i treće molare ${ }^{10}$.

Donji alveolarni nerv se unutar mandibularnog kanala može nalaziti blizu korena zuba 
enter the mandible in the retromolar fossa area to supply the first and third molars ${ }^{10}$.

IAN within the mandibular canal may lie close to the roots of the teeth or it may be much lower in the mandible near its lower border ${ }^{3}$. More commonly, the nerve lies near the buccal side of the mandible ${ }^{11}$. It may be intimately related to the root of the third molar tooth and may groove it, in the case of which the nerve may be at risk during the biomechanical preparation of third molar leading to its permanent sensory dysfunction. IAN block failures occur in $44 \%$ to $81 \%$ of cases, which may be due to objective location of neurovascular bundle, or an anatomic variation. Studies have shown the anesthetic success rates of $75 \%-97 \%$ with peripheral nerve stimulator ${ }^{12}$. $25 \%$ of accurate blocks using radio-opaque dyes result in anesthetic failure due to the migration of anesthetic solution along the path of least resistance determined by fascial planes and structures encountered in the pterygomandibular space ${ }^{13}$.

The inferior alveolar neurovascular bundle was shown to be in contact or close to the lingual cortical plate between the mandibular and mental foramina. It often gives rise to several branches at each level ${ }^{14}$. Absence of the ipsilateral inferior alveolar canal, nerve and mental foramen are of importance to clinicians who deal with surgery ${ }^{15}$. Panoramic radiography can provide reasonable diagnostic accuracy in the preoperative evaluation of the relationship between third molars and the canal ${ }^{16}$. IAN and the molar root apices are sometimes very close, allowing pathologic periapical conditions to affect the nerve. The IAN can be damaged by traumatic-compressive or toxic injuries resulting in neurapraxia of this nerve. When the causative agent is removed, the damage of the Schwann cells and the impairment of the myelin sheath can heal completely, thus making the clinical recovery predictable.

\section{Accessory innervation of teeth by mylo- hyoid nerve}

Mylohyoid nerve innervation to mandibular teeth is approximately $60 \%$ and thus is the cause of many cases of anesthetic failure ${ }^{17}$. It supplies the pre-molar, canine, incisor teeth and sometimes the first molar 8,18 .

There are reports of mylohyoid nerve branches entering the mandible through retromental foramina, associated with the lingual cortical bone ili znatno niže blizu donje ivice mandibule ${ }^{3}$. Najčešće je bliži bukalnoj strani vilice ${ }^{11}$ i može biti blisko povezan sa korenom trećeg molara formirajući impresiju na korenskom kanalu, što predstavlja rizik prilikom biomehanijske pripreme zuba i može dovesti do trajne senzibilne disfunkcije. Blok anestezija neuspešna je $u$ $44 \%$ do $81 \%$ slučajeva zbog objektivne lokacije neurovaskularnog snopa ili zbog anatomskih varijacija. Ispitivanja su pokazala stopu uspeha od $75 \%-97 \%$ uz periferni nervni stimulator ${ }^{12}$. $25 \%$ uspešno ubrizganih blok anestezija uz pomoć radiografskog zasenčenja rezultira neuspehom zbog migracije rastvora anestetika duž linije najmanjeg otpora koja zavisi od fascijalnih pripoja i struktura koje se sreću u pterigomandibularnom prostoru ${ }^{13}$.

Donji alveolarni neurovskularni snop može biti u kontaktu ili vrlo blizu površine lingvalnog korteksa između mandibularnog i mentalnog otvora, često formirajući više ogranaka na različitim nivoima ${ }^{14}$. Odsustvo ipsilateralnog donjeg alveolarnog kanala, kao i nerva i bradnog otvora, od presudnog je značaja za hirurge pre intervencije ${ }^{15}$. Panoramska radiografija omogućava izvesni stepen dijagnostičke preciznosti prilikom procene odnosa mandibularnog kanala i trećih molara ${ }^{16}$. Donji alveolarni nerv je ponekad vrlo blizu vrhova korena molara, zbog čega patološki procesi u periapikalnoj regiji mogu zahvatiti sam nerv. Donji alveolarni nerv može biti oštećen usled traumatsko-kompresivne ili toksične povrede, što može dovesti do neuropraksije. Posle otklanjanja uzroka, oštećenje Švanovih ćelija i mijelinskog omotača može biti u potpunosti otklonjeno.

\section{Akcesorna inervacija zuba milohioi- dnim nervom}

Učešće milohioidnog nerva $u$ inervaciji mandibularnih zuba iznosi otprilike $60 \%$, što je u mnogo slučajeva uzrok neuspeha anestezije $^{17}$. Ovaj nerv inerviše premolare, očnjake, sekutiće i ponekad prve molare ${ }^{8,18}$.

Postoje izveštaji o ograncima milohioidnog nerva koji ulaze u mandibulu kroz retromentalne otvore povezane sa lingvalnom kortikalnom 
in the vicinity of the second premolar tooth. The mylohyoid nerve arises from the inferior alveolar nerve about 5 to $23 \mathrm{~mm}$ above the level of the mandibular foramen and enters the mandible at a point distant to the mandibular foramen ${ }^{18}$. Inferior alveolar nerve block in the vicinity of the mandibular foramen does not block the mylohyoid nerve most often, hence, mylohyoid nerve block in the vicinity of the retromental foramina is recommended. Sometimes, the branching of mylohyoid nerve occurs about $14.7 \mathrm{~mm}$ from the mandibular foramen ${ }^{19}$. This distance could also be beyond the area of diffusion of the deposited anesthetic in a conventional mandibular block, thus allowing the accessory nervous supply to continue. The contiguity of a supplementary branch of mylohyoid nerve with either the incisor teeth or the incisive nerve proper has been demonstrated $^{20}$. Communicating branch of the mylohyoid nerve to the lingual nerve contribute to the sensory innervation of the tongue. Thus, mylohyoid nerve block can lead to partial tongue anesthesia or lingual nerve lesion does not result in complete anesthesia of the anterior part of the tongue ${ }^{21}$ (Figure 1).

\section{Bifid inferior alveolar nerve}

Bifid inferior alveolar nerve can be detected easily on panoramic radiographs due to

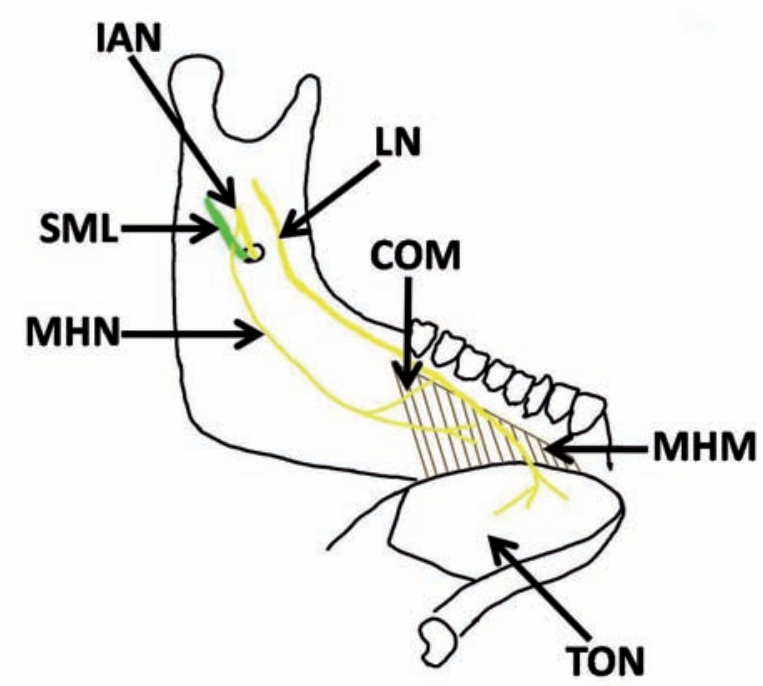

Figure 1. Figure illustrates the schematic representation of communication between the mylohyoid nerve (MHN) and lingual nerve $(L N)$. IAN-Main trunk of inferior alveolar nerve, COM-Communication between mylohyoid and lingual nerves, MHM- Mylohyoid muscle, TON- Tongue.

Slika 1. Šematski prikaz komunikacije između milohioidnog nerva (MHN) i lingvalnog nerva (LN). IAN glavno stablo donjeg alveolarnog nervam, MHM-milohioidni mišić, TON-Jezik lamelom u blizini drugog premolara. Milohioidni nerv odvaja se od NAI i ulazi u mandibulu u tački na oko 5 do $23 \mathrm{~mm}$ iznad nivoa mandibularnog otvora ${ }^{18}$. Blokada NAI u blizini mandibularnog formena najčešće ne dovodi do blokade milohioidnog nerva, stoga se preporučuje blokada milohioidnog nerva u blizini retromentalnih otvora. Ponekad, do grananja milohoidnog nerva dolazi na $14,7 \mathrm{~mm}$ od mandibularnog otvora $^{19}$. Ovo rastojanje, takođe, može biti van oblasti delovanja deponovanog anestetika pri standardnom mandibularnom bloku, tako da ne dolazi do isključivanja akcesornih nerava. Postoje primeri povezanosti ogranaka milohioidnog nerva i incizalnog nerva ${ }^{20}$. Komunikantna grana milohioidnog nerva prema lingvalnom nervu doprinosi sensitivnoj inervaciji jezika. Zbog toga, blokada milohioidnog nerva može dovesti do parcijalne anestezije jezika ili lezije lingvalnog nerva što neće dovesti do kompletne anestezije prednjih partija jezika ${ }^{21}$ (Slika 1).

\section{Bifidni nervus alveolaris inferior}

Bifidni nervus alveolaris inferior može biti lako uočljiv zahvaljujući prisustvu pomoćnog mandibularnog otvora i lingule. Kod pacijenata sa bifidnim kanalom nije primećen standardni

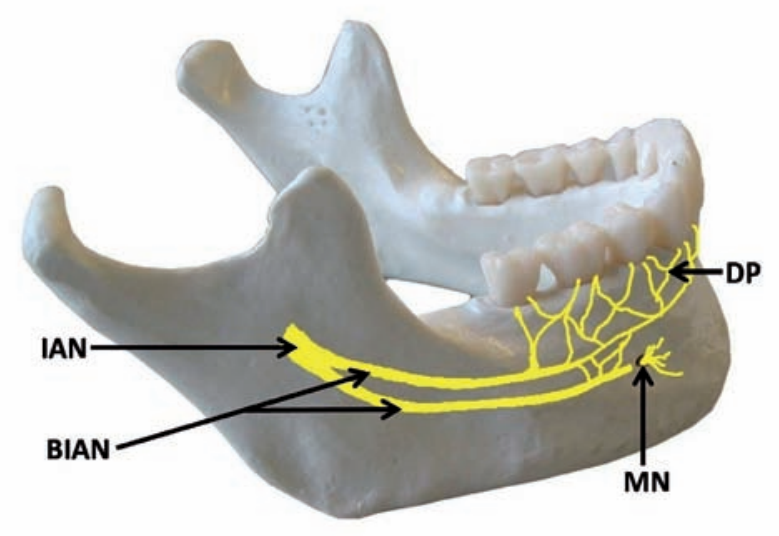

Figure 2. Figure illustrates the schematic representation of the bifid inferior alveolar nerve. IAN-Main trunk of inferior alveolar nerve, BIAN-Bifid branches of inferior alveolar nerve, DP-Dental plexus of nerves, $M N$ - Mental nerve.

Slika 2. Šematski prikaz bifidnog donjeg alveolarnog nerva. IAN-glavno stablo nerva, BIAN-Bifidne grane donjeg alveolarnog nerva, DP-pleksus dentalnih nerava, $M N$-mentalni nerv. 
the presence of an accessory mandibular foramen and lingulae. In patients with bifid canal, no specific pattern of division or duplication is seen $^{3}$. Because the bifurcation of the nerve occurs before entering the mandibular foramen, a normal inferior alveolar nerve block injection may be insufficient to block both branches. A high inferior alveolar nerve block may be effective in anesthetizing accessory nerve at or above its branch point. Only $0.08 \%$ bifurcation of the IAN is reported ${ }^{22}$. Evaluation of routine panoramic radiographs of 6.000 patients revealed $57(0.95 \%)$ cases of bifid mandibular canals ${ }^{23}$. The use of cone beam volumetric computed tomography has been shown to detect the incidence of bifid canals in $15.6 \%$ cases, a higher incidence than with use of panoramic radiographs ${ }^{24}$. As a second neurovascular bundle may be contained within the bifid canals, complications like traumatic neuroma, paraesthesia and bleeding could arise because of failure to recognize the presence of this anomaly. A case of trifid mandibular canal in panoramic radiographic study has been reported ${ }^{25}$. It is important for dentists to identify the presence of bifid or trifid canals to modify anesthetic techniques to avoid pain and discomfort to patients (Figure 2).

\section{Retromolar foramen}

Long buccal or early accessory branches of the inferior alveolar nerve provide accessory innervations to the mandibular molars through retromolar foramina. In almost $40 \%$ of human mandibles with retromolar foramina, the inferior alveolar nerve was contiguous with molar teeth via retromolar foramina ${ }^{26}$. Accessory innervations via retromolar entry can lead to difficulty in achieving local anesthesia of the mandibular molar area. To overcome this problem, a small amount of local anesthetic can be deposited directly into the tissue of the retromolar area $^{27}$. A high pterygoid entry injection can also be done but it would affect the inferior alveolar nerve in the pterygoid space before it gives any branches.

\section{Contralateral innervation of anterior teeth}

Incisive branch of inferior dental nerve is extensively branched and offers anastomoses obrazac podele ili duplikacije ${ }^{3}$. Baš zbog toga što se bifurkacija NAI dešava pre ulaza u mandibularni otvor, blok anestezija NAI može biti nedovoljna za obe grane. Visoka blokada NAI može biti uspešna pri anesteziranju akcesornog nerva u samoj tački grananja ili iznad nje. Zabeleženo je samo 0.08 procenata bifurkacije $\mathrm{NAI}^{22}$. Na osnovu procene rutinskih panoramskih radiografskih snimaka 6000 pacijenata zabeleženo je 57 slučajeva $(0.97 \%)$ bifidnog mandibularnog kanala ${ }^{23}$. Upotrebom CBCT moguće je otkriti prisustvo bifidnih kanala u $15,6 \%$ slučajeva, što je znatno veća učestalost od one otkrivene upotrebom panoramske radiografije. Komplikacije, kao što su traumatski neurom, parestezija i krvarenje, mogu se česće javiti ukoliko se ne prepozna anatomska anomalija poput prisustva sekundarnog neurovaskularnog snopa u bifidnom kanalu. Zabeležen je i slučaj trifidnog mandibularnog kanala na panoramskom radiografskom snimku ${ }^{25}$. Od važnosti je za stomatologa da identifikuje prisustvo bifidnog ili trifidnog kanala kako bi adekvatno modifikovao tehniku anestezije i izbegao neprijatnost i bol kod pacijenta (Slika 2).

\section{Retromolani otvor}

Dugi bukalni ili rani akcesorni ogranak NAI obezbeđuje dodatnu inervaciju mandibularnim molarima kroz retromolarne otvore. U skoro $40 \%$ ljudskih mandibula sa retromolarnim otvorima NAI je u kontaktu sa molarima putem retromolarnih otvora ${ }^{26}$. Dodatna inervacija preko retromolarnih otvora može dovesti do poteškoća u postizanju lokalne anestezije $\mathrm{u}$ predelu mandibularnih molara. Kako bi se prevazišao ovaj problem male količine lokalnih anestetika mogu se deponovati direktno u tkivo retromolarnog predela ${ }^{27}$. Anestetik može takođe biti ubrizgan visoko u pterigoidni prostor ali to može dovesti do blokade nerva u pterigoidnom prostoru pre njegovog grananja.

\section{Kontralateralna inervacija prednjih zuba}

Incizalna grana donjeg alveolarnog nerva obimno grana se i anastomozira u sredini donje vilice sa kontralateralnom stranom stvara- 
Figure 3. Figure illustrates the schematic representation of the contra-lateral innervation $(C O N)$ of the mandibular teeth (MT) by the inferior alveolar nerve (IAN). Also shown are mental nerve (MEN) and mylohyoid nerve (MYN). [Reproduced from Somayaji et al. Bratislava Med J. Article in press]

Slika 3. Šematski prikaz kontralateralne inervacije (CON) donjih zuba (MT) od strane donjeg alveolarnog nerva (IAN). Prikaz mentalnog nerva (MEN) i milohioidnog nerva (MYN). [Reprodukcija Somayaji i sar. Bratislava Med J. Article in press]

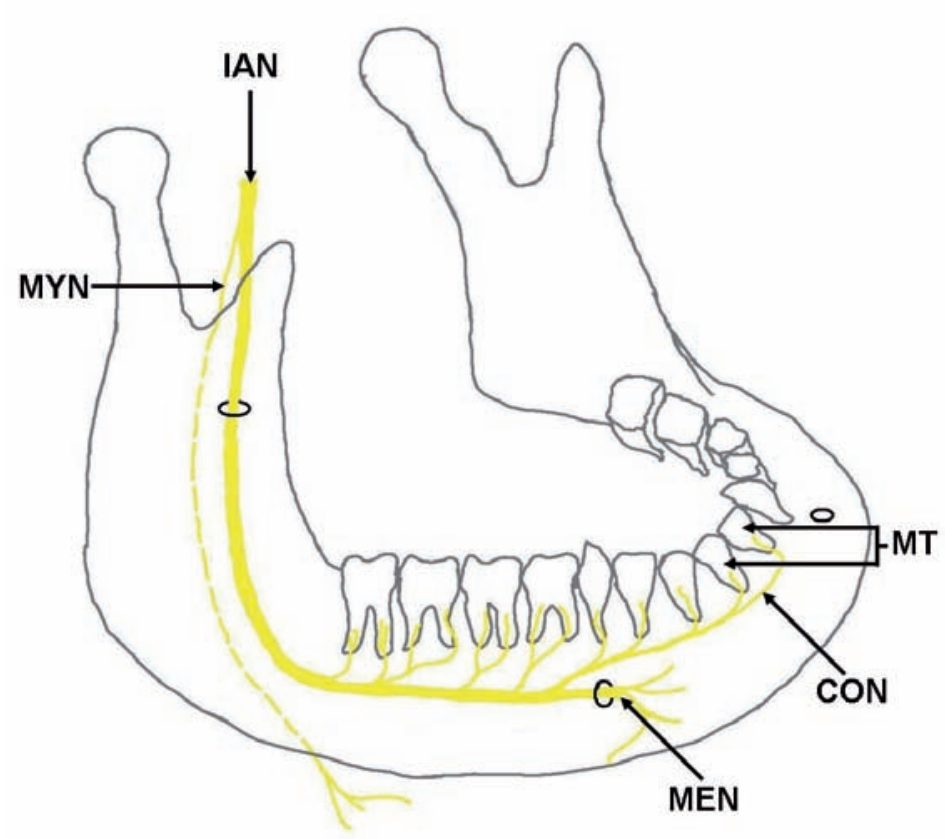

over the midline to the contralateral side, creating a crossover effect in the innervations of anterior teeth. The failure to anesthetize the incisors completely can be attributed to two things, 1. Crossover of the incisive branch 2 . The possibility of accessory innervations from buccal, facial, mylohyoid nerves and cervical plexus. ${ }^{28}$ When complete local anesthesia of the anterior teeth is not achieved after an ipsilateral mandibular block, steps must be taken to block sensation due to any potential crossover and/or accessory fibers and a contralateral incisive nerve block is opted. Achieving bilateral nerve blocks would rule out the possibility of failure caused by crossover. Mental/incisive nerve block or periodontal ligament injections are alternatives to bilateral mandibular nerve blocks for the procedures on the anterior part of the mandible. Bilateral mandibular nerve blocks create complete mandibular anesthesia leading to postoperative difficulties with speech, eating, drinking and salivary control. If the accessory innervation arises from the branches of the buccal, facial or cervical plexus, and these branches are traveling in the soft tissue of the area previous to the entry into the mandibular foramen, infiltration blocks may prove successful in determining the secondary innervations ${ }^{28}$ ( Figure 3 ).

\section{Mental nerve paraesthesia}

The common complaints due to the mental nerve paraesthesia include a transient or perma- jući ukršteni efekat u inervaciji prednjih zuba. Neuspeh potpune anestezije donjih inciziva može biti potpomognut dvema stvarima: 1 . ukrštanjem incizalnih grana; 2. postojanjem akcesorne inervacije od strane bukalnog, facijlanog, milohoidnog nerva i cervikalnog pleksusa $^{28}$. Kada je nemoguća potpuna anestezija prednjih zuba ipsilateralnom mandibularnom blokadom, moraju se preduzeti određeni koraci zbog ukrštenih i akcesornoh vlakana a jedna opcija je blokada kontralateralnog incizalnog nerva. Postizanje bilateralne nervne blokade isključilo bi mogućnost neuspeha uzrokovanog ukrštanjem nerava. Blokada mentalnog ili incizivnog nerva, kao i anesteziranje periodontalnog ligamenta predstavljaju alternativu bilateralne blokade mandibularnog nerva prilikom zahvata u prednjem delu mandibule. Bilateralnom blokadom mandibularnog nerva postiže se potpuna anestezija mandibule koja dovodi do postoperativnih poteškoća u govoru, ishrani, konzumaciji pića i kontroli salivacije. Ako akcesorna inervacija potiče od grana bukalnog nerva, facijalnog nerva ili cervikalnog pleksusa, a ove grane ne prolaze kroz meko tkivo pre nego uđu u mandibularni kanal, blokada može biti uspešna u utvrđivanju sekundarne inervaci$\mathrm{je}^{28}$ (Slika 3).

\section{Parestezija mentalnog nerva}

Česte žalbe pacijenata na paresteziju mentalnog nerva su prolazni ili trajni gubitak oseća- 
nent loss of sensitivity of the lip, chin and oral mucosa that is often associated with a limited intraoral xerostomia. The local factors like iatrogenic sequelae of endodontic therapy or surgical procedures and the occurrence of acute apical periodontitis or an acute exacerbation of a chronic apical periodontitis have been reported to be associated with mental nerve paraesthesia. The possible risk of hypersensitive reactions to potentially toxic or allergenic materials via the root canal has been reported ${ }^{29}$. After the removal of the restoration, the paraesthesia could be completely resolved.

\section{Maxillary Nerve}

The maxillary nerve block should be performed with utmost care to protect the pterygoid venous plexus in the pterygopalatine fossa.

\section{Variations of the maxillary nerve}

Six major types of variations of the maxillary nerve have been described. a. Missing middle superior alveolar nerve, $b$. Branch parallel to the infraorbital nerve supplying the upper lip, c. Bifid maxillary nerve, d. Posterior superior alveolar nerve innervating areas normally covered by the long buccal nerve, e. Branches from the pterygopalatine ganglion communicating with the abducent, optic or ciliary nerves, f. Various exchanges of nerve fibers among zygomaticofacial, zygomaticotemporal, infraorbital and lacrimal nerves ${ }^{30}$. Variations in the anatomic distribution of the maxillary nerve may explain the lack of uniformity in anesthesia by conduction or infiltration.

In the absence of middle superior alveolar nerve, the premolar region is supplied by a branch of anterior dental nerve which is mostly the largest of the superior dental nerves. A dental plexus formed by these dental nerves innervate the teeth in $48 \%$ of cases. One to three posterior superior alveolar branches from the maxillary nerve in the zygomatic region pass through canaliculi in the lateral wall of the maxillary sinus or under the mucous membrane of the sinus to form maxillary sinus plexus. Bony wall of the sinus separates this plexus from the superior dental plexus, located in the thick alveolar process of the maxilla and innervate the upper teeth ${ }^{31}$. ja na usni, bradi ili oralnoj sluzokoži, što je često udruženo i sa ograničenom intraoralnom kserostomijom. Postoje primeri da lokalni uzroci kao što je jatrogeni faktor u endodonskim ili hirurškim procedurama ili prisustvo akutnog apikalnog paradontita kao i akutne egzacerbacije hroničnog apikalnog parodontita mogu biti udruženi sa parestezijom mentalnog nerva. Takođe je zabeležen moguć rizik hipersenzitivne reakcije na moguće toksične i alergene materijale koje prodiru kroz kanal korena ${ }^{29}$. Posle uklanjanja ispuna parestezija može u potpunosti nestati.

\section{Maksilarni nerv}

Blok maksilarnog nerva mora se izvesti sa najvećom pažnjom kako bi se zaštitio venski pterigoidni pleksus u pterigoplatinskoj jami.

\section{Varijacija maksilarnog nerva}

Opisano je 6 najčešćih varijacija maksilarnog nerva: a. nedostatak srednjeg gornjeg alveolarnog nerva, b. ogranak paralelan infraorbitalnom nervu koji inerviše gornju usnu, c. bifidni maksilarni nerv, d. polje gornjeg zadnjeg alveolarnog nerva normalno pokriveno dugim bukalnim nervom, e. ogranci pterigopalatinskog gangliona koji komuniciraju sa abducensom, optičkim ili cilijarnim nervom, f. raznovrsne promene nervnih vlakana duž zigomatikofacijalnog, zigomatikotemporalnog, infraorbitalnog i lakrimalnog nerva ${ }^{30}$.

Varijacije u anatomskoj distribuciji maksilarnog nerva mogu objasniti nedostatak standarne reakcije na anesteziju u pogledu sprovodljivosti ili infiltracije.

U odsustvu srednjeg gornjeg alveolornog nerva premolarna regija je inervisana ograncima prednjeg gornjeg alveolarnog nerva koji je uglavnom najveći od gornjih dentalnih nerava. Dentalni pleksus koji se sastoji od ovih dentalnih nerava, inerviše zube u $48 \%$ slučajeva. Jedna do tri zadnje alveolarne grane koje potiču od maksilarnog nerva u zigomatičnom regionu prolazi kroz kanaliće u spoljnem zidu maksilarnog sinusa ili ispod sluzokožne opne sinusa formirajući pleksus maksilarnog sinusa. Koštani zid sinusa deli ovaj pleksus od gornjeg dentalnog pleksusa koji se nalazi u tankom zidu alveolarnog nastavka maksile i inerviše gornje zube $^{31}$. 


\section{Maxillary sinus}

The floor of the maxillary sinus can be very thin and in some individuals the roots of the posterior teeth project through it. In these cases, the root tips are covered only by the Schneiderian membrane of respiratory epithelium which lines the maxillary sinus ${ }^{32}$. The distance between the root apices of the maxillary posterior teeth and the sinus is sometimes less than $1 \mathrm{~mm}^{33}$. Great care must be taken during endodontic treatment, not to accidentally introduce foreign bodies into the antrum. The most commonly found foreign bodies are the displaced fractured roots of teeth, dental burs, gutta percha points and silver points ${ }^{34}$. During the root canal treatment, the possibility of communication of the canal system with surrounding tissue should be determined both clinically and radiographically. The recent advance like cone beam volumetric computerized tomography is proven to be better aid in diagnosing maxillary sinusitis due to failed endodontic treatment ${ }^{35}$. Overzealous preparation of root canal may cause extrusion of debris into the sinus leading to inflammatory reaction and delayed healing ${ }^{36}$. Incidence of sodium hypochlorite accident into the sinus and then to the pharynx has been reported $^{37}$. Sodium hypochlorite elicits inflammatory reaction and is cytotoxic to all cells. This can be avoided by irrigating the solution carefully ${ }^{37}$.

Intracanal medicament placed between appointments may extrude into the sinus. The use of calcium hydroxide is irritant to sinus tissue and has immediate degenerative effects on cells; before the material is removed by macrophages and foreign body giant cells ${ }^{38,39}$. The calcium hydroxide causes inflammatory response of sinus mucosa, which initially acts as irritant and later as foreign body ${ }^{40}$. Extrusion of sealers like N2 into the sinus leading to severe pain has been reported ${ }^{41}$. Occasionally, foreign intra-sinusal bodies were seen as a result of different endodontic treatments of posterior maxillary teeth ${ }^{42}$.

Gutta percha evokes two distinct types of tissue responses that are determined by the size and surface character of the material: 1) In case of large piece of gutta percha, the surrounding tissue is free of inflammation and gutta percha is well encapsulated. 2) Fine particles of gutta percha evoke localized tissue response characterized by the presence of macrophages

\section{Maksilarni sinus}

Pod maksilarnog sinusa može biti jako tanak tako da kod pojedinaca korenovi bočnih zuba prodiru kroz isti. U ovim slučajevima vrhovi korenova su prekriveni samo Shneider-ovom membranom respiratornog epitela koji oblaže maksilarni sinus ${ }^{32}$. Udaljenost između vrhova korenova maksilarnih bočnih zuba i sinusa nekada je manja od $1 \mathrm{~mm}^{33}$. Endodontski tretman mora biti obavljen uz veliku pažnju, da ne bi došlo do slučajnog prodiranja stranog tela u antrum. Strana tela, najčešće pronađena u maksilarnom sunusu, parčići su polomljenih korenova zuba, dentalna svrdala, gutaperka štapici i srebrni kočići ${ }^{34}$. U toku obrade kanala korena mogućnost komunikacije kanalnog sistema sa okolnim tkivom trebalo bi proveravati radiografski i klinički. Cone Beam volumenska kompjuterizovana topografija, kao skorašnji napredak u tehnologiji snimanja, pokazala se kao bolje pomoćno sredstvo u dijagnostici maksilarnog sinuzita kao posledice neuspešnog endodontskog tretmana ${ }^{35}$. Previše agresivna obrada kanala korena može dovesti do utiskivanja debrisa u sinus koji dovodi do zapaljenske reakcije i otežanog zarastanja ${ }^{36}$. Prijavljeni su i slučajevi slučajog ubacivanja natrijum hipohlorita $\mathrm{u}$ sinus $\mathrm{i}$ farinks ${ }^{37}$. Natrijum hipohlorit izaziva zapaljensku reakciju i ima citotoksični efekat. Ovo može biti izbegnuto pažljivom irigacijom ${ }^{37}$.

Intrakanalni medikamenti koji se stavljaju u kanal između dve seanse mogu biti utisnuti u sinus. Upotreba kalcijum hidroksida iritira tkivo sinusa $i$ ima trenutni degenerativni efekat na ćelije sve do odstranjivanja uz pomoć makrofaga i gigantskih ćelija tipa stranog tela ${ }^{38,39}$. Kalcijum hidroksid izaziva inflamatorni odgovor sinusne sluzokože i u početku je iritira a kasnije dobija efekat stranog tela. ${ }^{40}$. Ima podataka da ekstruzija punjenja, poput $\mathrm{N} 2$ u sinus, izaziva veliki bol $^{41}$. Ponekad se strana tela u sinusu vide kao posledica endodontskog tretmana gornjih zadnjih zuba ${ }^{42}$.

Guteperka pobuđuje dva različita tipa tkivnog odgovora, koji zavise od veličine i površinskih karakteristika materijala. 1) U slučaju da je parče guteperke veliko, ne dolazi do inflamacije okolnog tkiva i guteperka biva dobro inkapsulirana. 2) Sitniji i finiji parčići guteperke izazivaju lokalnu tkivnu reakciju koju karakteriše prisustvo makrofaga i multinukleusnih gigantskih 
and multinucleated giant cells ${ }^{43}$. Factors with bone resorbing activity are released when gutta percha is exposed to mouse peritoneal macrophages $^{44}$. The use of 'step back' technique in preparing the root canal and the placement of an initial principal point followed by further additional points using lateral condensation may prevent the extrusion of filling materials from the apex ${ }^{45}$. There are reports of silver points corroding when they come into contact with saliva leading to the formation of silver sulphate, silver sulphide and silver carbon ${ }^{46}$. Anatomic structures have to be considered during the treatment planning of endodontic stabilizer. Extension of endodontic implant into the sinus may lead to complication ${ }^{47}$. Periapical infection spreads through the bone marrow following the path of blood vessels and lymphatics ${ }^{48}$. Symptoms associated with acute or subacute sinusitis can be mistaken for those of pulpal origin $^{49}$. Sinusitis presents with dull pain, generally unilateral during mastication or feeling of fullness around molar and premolar area ${ }^{36}$. Increase in pain may be observed when lying down. ${ }^{36}$ The sinus may be tender on tapping 50 . The affected tooth may also be moderately tender, but the pulpal status will respond normal$1 y^{51}$. If only one tooth exhibits pain or is tender to percussion, then one should suspect pain of pulpal origin ${ }^{52}$. Transillumination is an aid that helps in differentiating pulpal pain from sinusitis, where the decreased transmission indicates sinus congestion. If the pain is of sinus origin, it will be eliminated in one to two minutes by the placement of cotton swab saturated with $5 \%$ lidocaine deeply in the nostrils of the affected site for 20 to 30 seconds $^{36}$. Pain of dental origin may range from thermal sensitivity to sharp pain $^{36}$. Endo-antral syndrome (EAS) is the spread of pulpal disease beyond the confines of the dental supporting tissues into the maxillary sinus which shows one or more of the following features: (1) Pulp disease in a tooth whose apex approximates the floor of the maxillary sinus. (2) Periapical radiolucency on pulpally involved tooth. (3) Radiologic loss of lamina dura defining the inferior border of the maxillary sinus over the pulpally involved tooth. (4) A faintly radio-opaque mass bulging into the maxillary sinus above the apex of the involved tooth connected neither to the tooth nor to the lamina dura of the tooth socket. (5). Varying degrees of radiopacity of the surrounding sinus space. The variable presentation of the EAS can create both diagnostic and therapeutic difficul- ćelija $^{43}$. Faktori koštane resorpcije oslobađaju se kada prisustvo guteperke izazove aktivaciju peritonealnih makrofaga za resorpciju stranog tela ${ }^{44}$. Upotrebom stepbek tehnike u obradi korenskog kanala i plasiranje početnog štapića kao i dodatnih štapića upotrebom lateralne kondenzacije može se sprečiti ekstruzija punjenja iz apeksa ${ }^{45}$. Zabeleženi su slučajevi korodiranja srebrinih kočića posle dolaženja u kontakt sa pljuvačkom, pri čemu dolazi do formiranja srebro sulfata, srebro sulfida i srebro karbida ${ }^{46}$. Potrebno je razmotriti anatomske strukture prilikom planiranja tretmana endodontskim stabilizatorom. Ekstenzija endodontskog implanta u maksilarni sinus može dovesti do komlikaci$\mathrm{ja}^{47}$. Periapikalna infekcija se širi kroz koštanu srž prateći put krvnih sudova i limfatika ${ }^{48}$. Simptomi udruženi sa akutnim sinuzitom mogu biti pomešani sa pulpitičnim tegobama ${ }^{49}$. Kod sinuzitisa postoji prisustvo tupog bola najčešće jednostranog, u toku mastikacije ili osećaj punoće u regiji premolara i molara ${ }^{36}$. Bol se može pojačati u ležećem polozaju ${ }^{36}$. Sinus može biti osetljiv na perkusiju ${ }^{50}$. Zub uzročnik može takođe biti umereno osetljiv ali pulparni status će i dalje biti normalan ${ }^{51}$. Ako je samo jedan zub bolan ili perkutorno osetljiv, treba sumnjati na bol pulparnog porekla ${ }^{52}$. U ovom slučaju može se koristiti transimulacija u cilju razlikovanja pulparnog bola od sinuzita, kada umanjen prenos osećaja bola ukazuje na kongestiju sinusa, simulacija u cilju razlikovanja pulparnog bola od sinuzitisa, kada umanjen prenos osećaja ukazuje na kongestiju sinusa. Ako je bol sinusnog porekla, prestaće u roku od jednog do dva minuta nakon stavljanja pamučnog bris štapića natopljenog 5\% lidokainom duboko u nozdrve ili na bolno mesto u roku od 20 do 30 sekundi. Bol dentalnog porekla može se rangirati od termičke osetljivosti do oštrog bola ${ }^{36}$. Endoantralni sindrom (EAS) koji inače predstavlja širenje pulpalnog oboljenja van okvira tkiva koje ga okružije u maksilarni sinus, ima nekoliko odlika: (1) oboljenje pulpe kod zuba čiji apeks doseže do poda maksilarnog sinusa. (2) periapikalno rasvetljenje na zubu sa prisustvom pulpe. (3) radiografski gubitak lamine dure koja čini donju granicu maksilarnog sinusa iznad zuba sa prisustvom pulpe. (4) slaba radiološka senka koja prodire u sinus iznad vrha zuba sa pulpom koja nije povezana niti sa lamina durom niti sa alveolom. (5) varijabilni stepen radiološke osenčenosti prostora koji okružuje sinus. Različite prezentacije EAS mogu dovesti do dijagnostičkih i terapijskih poteškoća zbog 
ties, because all cases do not often exhibit evidence of all five features.

Cases have been reported, where spreading of dental infection through the sinus leading to periorbital cellulitis, blindness and also cavernous sinus thrombosis. Intracranial extension of infection can occur by two mechanisms: (a) directly, by erosion through the posterior wall of the frontal sinus; and (b) indirectly, by thrombophlebitis or septic emboli via emissary veins $^{53,54}$. Aspergillosis is often associated with concretions in the maxillary sinus, which on the basis of radiological and clinical findings have been considered to correspond to dental restorative material. Zinc in maxillary sinus promotes the growth of Aspergillus species. In endodontics, zinc oxide eugenol-based sealers which are used may trigger the fungal infection ${ }^{55,56}$ (Figure 4).

\section{Considerations of sinus in endodontic surgery}

Perforation of the sinus during surgery is fairly common with a reported incidence of about 10 to $50 \%$ of cases 57 . In 146 reported cases of sinus exposure during periradicular surgery, there was no difference in their healing when compared with similar surgical procedures without sinus exposure ${ }^{36}$. The sinus membrane usually regenerates and a thin layer of new bone often forms over the root end, although osseous regeneration is less predictable ${ }^{58}$. About $0.8-7 \mathrm{~mm}$ thick bone separates

Figure 4. Picture of the maxilla showing the obturating material (OM) extending into the maxillary air sinus (MS).

Slika 4. Slika koja prikazuje maksilu sa opruracionim materijalom (OM) koji se pruža u šupljinu maksilarnog sinusa (MS) toga što u svim slučajevima nije prisutno svih 5 navedenih odlika.

Zabeleženi su slučajevi širenja dentalne infekcije u sinus koja je dovela do periorbitalnog celulitisa, slepila i tromboze kavernoznog sinusa. Intrakranijalno širenje infekcije dešava se na dva načina: a) direktno kroz erodirani zadnji zid frontalnog sinusa, b) indirektno tromboflebitom ili septičkom embolijom emisarnih vena ${ }^{53,54}$. Asperogiloza je često udružena sa konkrementima u maksilarnom sinusu koji se na osnovu radioloških i kliničkih ispitivanja smatraju povezanim sa materijalima za restauraciju zuba. Cink u maksilarnom sinusu pospešuje rast vrsta Asperogilusa. Punjenja na bazi cink-oksideugenol-a koja se koriste u endodonciji mogu poslužiti kao okidač za nastanak gljivične infekcije ${ }^{55,56}$ (Slika 4).

\section{Uloga sinusa u endodontskoj hirurgiji}

Otvaranje sinusa prilikom hirurške intervencije je prilično često sa prijavljenom učestalošću od 10 do $50 \%$ sučajeva ${ }^{57}$. U 146 prijavljenih slučajeva otvaranja sinusa u toku periradikularne hirurgije nije bilo razlike u zarastanju u poređenju sa sličnim hirurškim procedurama u kojima nije došlo do otvaranja sinusa $^{36}$. Sinusna membrana se obično regeneriše i tanak sloj nove kosti se često formira na kraju vrha korena, mada je regeneracija kosti predvidiva $^{58}$. Oko 0.8 do $7 \mathrm{~mm}$ tanke kosti odvaja vrh korena zuba od sinusa u bočnim segmentima

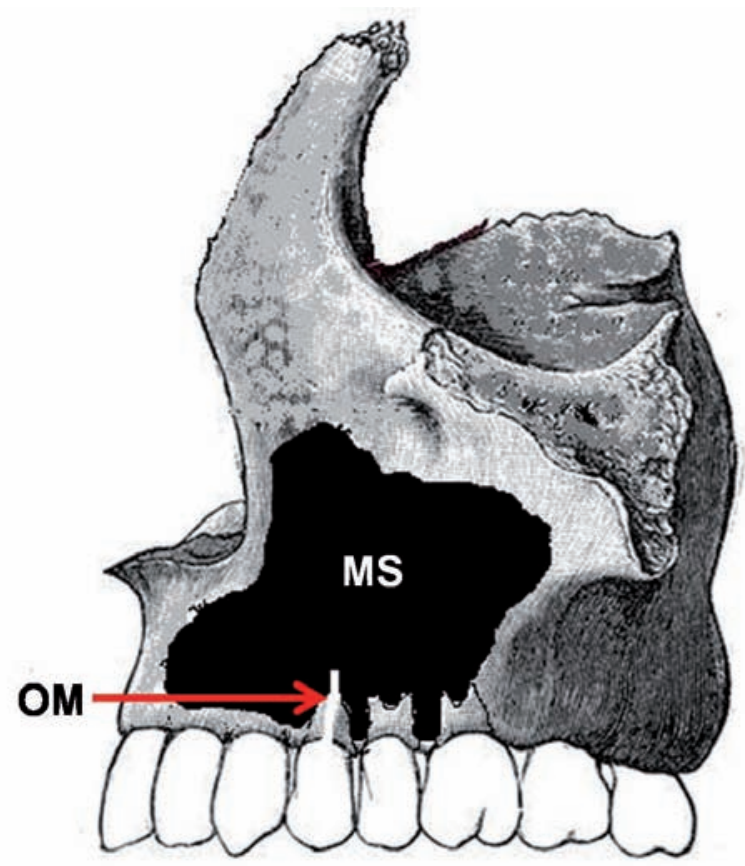


the teeth apices in the lateral segments of the maxilla from the sinus ${ }^{59}$. Adequate infiltration anesthesia in the region of the vestibule of the mouth and the palate at the level of the root apex suffices even when the sinus is locally affected $^{58}$. When the maxillary canine tooth and premolars are resected, additional nerve blocking in the region of the infraorbital foramen can be carried out ${ }^{58}$. A vertical releasing incision should be made at least one tooth mesial and distal to the surgical site, especially in cases when sinus perforation is possible, because the exposure site should be completely covered with mucoperiosteal flap to provide primary closure $^{60}$. Displacement of root tip into the sinus can be avoided by cutting through the bone and approaching the root from front and below but never from above ${ }^{61}$. The root tip is then burred off to the desired level. The debris that is produced during this procedure may enter the sinus and cause inflammation. ${ }^{61}$. Another method of preventing displacement of root into sinus is drilling a small hole at root apex and securing it with a suture before apicoectomy ${ }^{62}$. The palatal roots of maxillary molars present a special challenge for surgical access. Palatal roots are $50 \%$ closer to the sinus than are to the palate ${ }^{60}$. They show apical communication with the sinus in $20 \%$ of the cases and are less than $0.5 \mathrm{~mm}$ from the sinus in $40 \%$ of cases. The transantral approach is reflecting the buccal flap, resecting the buccal root, then enlarging the osteomy access into the sinus to approximately 1 to $1.5 \mathrm{~cm}$. Then palatal root tip is dissected, ultrasonically prepared and filled ${ }^{63}$. The position of the anterior palatine artery must be carefully considered when the incision is made and the flap is reflected ${ }^{60}$. The vertical releasing incision may be placed distal to the second molar, but should not approach the junction of the alveolar process and roof of the palate. When the anterior palatine artery is severed, local clamping and pressure may not stop the hemorrhage. In such cases, the ligation of the external carotid artery may be necessary ${ }^{60}$.

\section{Temporomandibular joint (TMJ)}

Symptoms elicited by pulpalgia may mimic temporomandibular disorder (TMD) like pain. Increase in pain due to cold stimulus on affected tooth confirms that the pulpalgia is contributing to the pain ${ }^{64}$. Pain due to pulpalgia is mostly localized to the responsible tooth, but some patients may complain pain that refers maksile. Odgovarajuća infiltraciona anestezija u vestibularnom regionu i u predelu nepca u nivou vrha korena dovoljna je kad je sinus lokalno ugrožen ${ }^{58}$. Kada se maksilarni očnjaci i premolari reseciraju, treba sprovesti dodatnu blokadu nerva u predelu infraorbitalnog otvo$\mathrm{ra}^{58}$. Vertikalni rez treba napraviti najmanje zub mezijalno i jedan zub distalno od hirurškog mesta, naročito u slučajevima kada postoji mogućnost otvaranja sinusa, zato što mesto otvaranja sinusa mora biti kompletno pokriveno mukoperostalnim režnjem kako bi se obezbedilo primarno zatvaranja ${ }^{60}$. Utiskivanje vrha korena $u$ sinus može se izbeći presecanjem kroz kost $\mathrm{i}$ prilaženjem korenu sa donje i prednje strane ali nikad sa gornje. Korenski vrh se onda obrađuje do željenog novoa. Debris koji se stvara u toku ove procedure može dospeti u sinus i izazvati zapaljenje $^{61}$. Drugi metod za prevenciju neželjenog dospeća korena u sinus je bušenje male rupe na vrhu apeksa i osiguravanje iste šavom pre apikoektomije ${ }^{62}$. Palatinalni korenovi maksilarnih molara predstavljaju poseban rizik za uspeh hirurške intervencije. Palatinalni korenovi su $50 \%$ bliži sinusu nego nepcu ${ }^{60}$. Oni pokazuju apikalnu komunikaciju sa sinusom u 20\% slučajeva i udaljenost od $0.5 \mathrm{~mm}$ od sinusa $u$ $40 \%$ slučajeva. Transantralni prilaz se radi odizanjem bukalng režnja, resekcijom bukalnog korena a zatim proširenjem osteotomskog prilaza sinusu u proseku 1 do $1.5 \mathrm{~cm}$. Tada se vrh platinalnog korena disecira, ultrasonički priprema i puni ${ }^{63}$. Pozicija prednje platanalne arterije mora se posebno uzeti u obzir prilikom pravljenja incizije i podizanja režnja ${ }^{60}$. Vertikalna incizija se može produžiti do drugog molara ali ne bi trebalo da dođe u blizinu spoja alveolarnog nastavka i krova nepca. Kada dođe do presecanja prednje palatanalne arterije, lokalna komresija ne može zaustaviti krvarenje. U ovim slučajevima je neophodna ligatura arterije karotis eksterne ${ }^{60}$.

\section{Temporomandibularni zglob (TMZ)}

Pulpitične tegobe mogu imitirati temporomandibularne smetnje poput bola. Bol koji se pojačava na hladne stimulanse na zahvaćenom zubu potvrđuju da se radi o bolu izazvanom oboljenjem pulpe ${ }^{64}$. Pulpitični bol je uglavnom lokalizovan u predelu bolnog zuba, ali se pacijenti nekad mogu žaliti i na bol koji se širi pre- 
more broadly to the jaw and mimics the location and quality of TMD pain. TMD pain is usually an ache, pressure, dullness or all of these may include a background burning sensation, generally located in the masseter muscle or preauricular and / or anterior temporalis muscle regions. There may be episodes of sharp pain which may become throbbing. Palpation of the location of pain reproduces or intensifies the pain. TMD pain aggravates to stress, clenching and eating, whereas it is relieved by relaxing, applying heat to the painful area, taking over the counter analgesics or all of these. Referred pulpal pain is difficult to localize to a specific tooth, often also causes pain in the masseter muscle or the preauricular and or anterior temporalis muscle regions; and can cause tightness in the masticatory muscles ${ }^{65}$. The two primary mechanisms for referred pain are central convergence and central sensitization. More nerve fibers carry information into the central nervous system than the number of neurons that transfer this information to the higher center. This needs the information carried by the multiple nerve fibers to be consolidated to fewer neurons carrying this information to the higher centers. This results in the higher centers to perceive the information from two or more regions ${ }^{66}$. Central sensitization occurs from a continuous barrage of painful input activating receptors that increase the sensitization of second order neurons, altering normal processing to the higher centers, expanding the receptive field area and causing nonpainful information to be relayed as painful ${ }^{67}$. Central convergence and central sensitization may occur in both the sensory trigeminal nuclei and thalamus (Figure 5). It has been demonstrated that when an inflam- ma vilicama i imitira lokaciju i osobine bola $u$ TMZ. TMZ smetnje najčešće uključuju senzaciju bola, pritiska, tupoće ili svega navedenog, kao i osećaj žarenja, uglavnom lokalizovan na maseteričnom mišiću ili u predelu preaurikularnog/prednjeg temporalnog mišića. Mogu se pojaviti i napadi oštrog bola koji može postati pulsirajući. Palpacija bolnog mesta ponovo izaziva ili pojačava bol. TMZ bol se pojačava stresom, stiskanjem zuba i žvakanjem, a umanjuje se aplikovanjem toplote na bolno područje i upotrebom standardnog analgetika. Iradirajući pulparni bol je teško lokalizovati i često izaziva bol u masteričnom mišiću ili predelu preaurikularnog/prednjeg temporalnog mišica i može uzrokovati zatezanje mastikatorne muskulature $^{65}$. Dva glavna mehanizma iradirajućeg bola su centralno spajanje i centralna senzacija. Većina nervnih vlakana nosi informaciju do centralnog nervnog sistema a onda brojni neuroni prebacuju ovu informaciju u više centre. Ovo podrazumeva da se informacija koju nose višebrojna nervna vlakna svede na manji broj neurona koji je dalje nose do viših centara. Kao rezultat, viši centri informaciju vezuju za dve ili vise rezličitih regija. Dva su primarna mehanizma odgovorna za nastajanje iradirajućeg bola: centralna konvergencija i centralna senzitizacija. Više nervnih vlakana prenosi informaciju u centralni nervni sistem od broja neurona koji prenose ovu informaciju u više centre. Trebalo bi da informacija koju nosi veći broj nervnih vlakana bude konsolidovana na nekoliko neurona koji je prenose u više centre. Ovo rezultira time da viši centri dobijaju informaciju iz dva ili više regiona ${ }^{66}$. Centralna senzitizacija nastaje kontinuiranom baražom bolnih aktivatinskih receptora koji povećavaju senzitizaciju drugog reda neurona, prosleđujući normalnu obradu informacije višim centrima, na taj način šireći

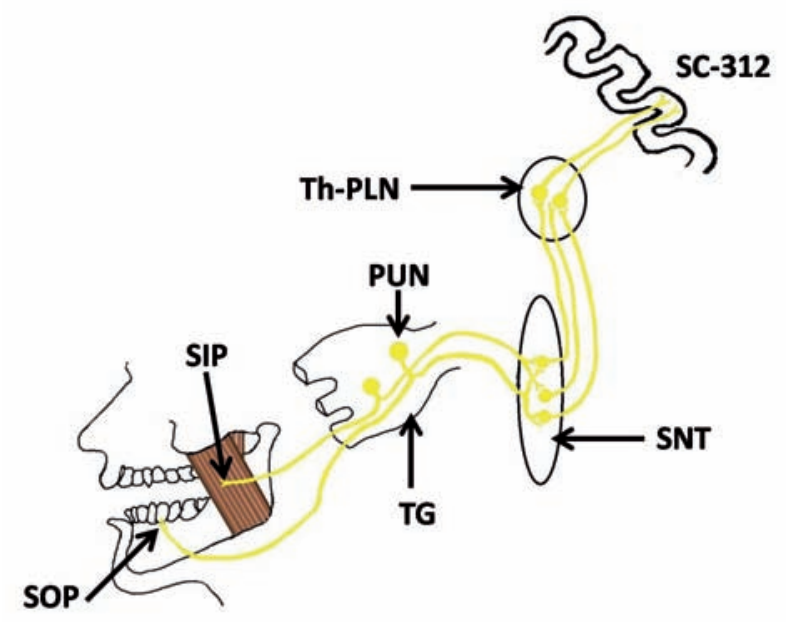

Figure 5. Schematic representation of central convergence and sensitization of pain. SOP-Origin of pain, SIP-site of pain referred, TG-Trigeminal ganglion, PUN-Pseudounipolar neurons, SNT- Spinal nucleus of trigeminal nerve in medulla obolngata, Th PLN- Posterior lateral nucleus of thalamus, SC-312-Primary sensory area on the postcentral gyrus of the cerebral cortex.

Slika 5. Šematski prikaz centralnog spajanja i senzacije bola SOP-poreklo bola, SIP-mesto gde se bol pojavljuje, TGtrigeminalni ganglion, PUN-pseudounipolarni neuroni, SNTspinalno jedro truigeminalnog nerva u produženoj moždini, Th PLN-zadnje spoljnje jedro talamusa, SC-312-primarno senzorno polje postcentralnog girusa cerebralnog korteksa 
matory irritant is placed on dental pulps, electromyograhic activity of masticatory muscles increases ${ }^{64}$. This finding may explain pain due to pulpalgia, which after ligamentary injection, will not cause tightness in masticatory muscles and have a greater range of joint motion. Central sensitization can also be produced by glial cells that are activated by inflammatory irritants placed on dental pulps ${ }^{68}$.

\section{Role of salivary glands}

Saliva controls the plaque $\mathrm{pH}$ and regulates the oral flora. Dental carries is a common clinical finding associated with xerostomia due to salivary hypofunction. Absence of salivary glands will lead to decrease in salivation, which eventually results in rapid spread of caries with pulpal involvement ${ }^{69}$.

\section{Conclusion}

Basic anatomical knowledge is vital for many successful dental procedures. Awareness of maxillary sinus involvement and complications due to endodontic treatments of upper teeth makes dentists to be very cautious. It also prepares the clinician for the differential diagnosis of symptoms of teeth and other orofacial regions. Concept of anatomical variations is of utmost importance to prevent complications of anesthetic procedures. Such a review of available literature regarding the anatomical anomalies of structures encountered by the dentists during their clinical practice will be useful for better patient care. receptorno područije i dovodeći do toga da se informacije koje nisu bolne ispoljavaju kao bolne ${ }^{67}$. Centralna konvergencija $i$ centralna senzitizacija mogu se odvijati i u senzitivnom trigeminalnom jedru i u talamusu (Slika 5.). Dokazano je da kada se inflamatorni iritans postavi na zubnu pulpu, elektromiografska aktivnost mastikatornih mišića raste ${ }^{64}$. Ova otkrića mogu objasniti bol u toku pulpalgije, koji posle ligamentarne injekcije neće izazvati zatezanje mastikatornih mišića i postojaće veća mogućnost pokreta u zglobu. Centralna senzitizacija takođe može biti proizvedena glijalnim ćelijama koje se aktiviraju postavljanjem inflamatornog iritansa na zubnu pulpu ${ }^{68}$.

\section{Uloga pljuvačnih žlezdi}

Pljuvačka kontroliše $\mathrm{pH}$ plaka i oralnu floru. Zubni karijes se često sreće u sklopu kserostomije- hipofunkcije pljuvačne žlezde. Nedostatak pljuvačnih žlezdi dovodi do smanjenja salivacije koja može dovesti do brzog širenja karijesa i oboljenja pulpe ${ }^{69}$.

\section{Zaključak}

Poznavanje anatomije je od vitalnog značaja za mnoge stomatološke procedure. Svest o blizini maksilarnog sinusa i komplikacije koje su skopčane sa endodontskim procedurama utiču na lekara da bude veoma obazriv. Takođe, upućuju kliničara na diferencijalnu dijagnozu oboljenja orofacijalne regije. Koncept anatomskih varijacija od najveće je važnosti za sprečavanje komplikacija u toku anestezioloških procedura. Ovakav pregled varijacija anatomskih struktura sa kojima se susreću lekari u toku svog kliničkog rada biće koristan za bolje zbrinjavanje pacijenata. 
1. Kiesselbach JE, Chamberlain JG. Clinical and anatomical observations on the relationship of the lingual nerve to the mandibular third molar region. J Oral Maxillofac Surg 1984; 42:565-567.

2. Anderson LC, Kosinski TF, Mentag PJ. A review of the intraosseous course of the nerves of the mandible. J Oral Implantol 1991; 17:394-403.

3. Nortje CJ, Farman AG, Grotepass FW. Variations in the normal anatomy of the inferior dental (mandibular) canal: a retrospective study of panoramic radiographs from 3612 routine dental patients. Br J Oral Surg 1977; 15:55-63.

4. Kim SY, Hu KS, Chung IH, Lee EW, Kim HJ. Topographic anatomy of lingual nerve and variation in communication pattern of the mandibular nerve branches. Surg Radiol Anat 2004; 26:128-135.

5. Suzao I, Cantin M, Zavando D. Inferior alveolar nerve block anesthesia via retromolar triangle, an alternative for patients with blood discrasias. Oral Surg Oral Med Oral Pathol Endod 2008; 13:43-47.

6. Anil T, Peker HB, Turgut IN, Gülekon, Liman F. Variations in the anatomy of the inferior alveolar nerve. Br J Oral Maxillofac Surg 2003; 41:236-239.

7. Ortu G, Moriggl B. Studies about the topography of the maxillary artery within the infratemporal fossa. Anat Anz 1991; 172:197-202.

8. Lacouture C, Blanton PL, Hairston LE. The anatomy of the maxillary artery in the infratemporal fossa in relationship to oral injections. Anat Rec 1983; 205:104A.

9. Afsar A, Haas DA, Rossouw PE, Wood RE. Radiographic localization of mandibular anesthesia landmarks. Oral Surg Oral Med Oral Pathol Oral Radiol Endod 1998;86: 234-241.

10. Haveman CW, Tebo HG. Posterior accessory foramina of the human mandible. J Prosthet Dent 1976; 35:462-468.

11. Miller CS, Nummikosi PV, Barnett DA, Langlais RP. Cross-sectional Tomography. A diagnostic techniquefor determinijg the buccolingual relationship of impacted third molars and inferior alveolar neurovascular bundle. Oral Surg Oral Med Oral Pathol 1990;70:791-797.

12. Simon F, Reader AL, Melisa D, Nusstin J, Beck M. A Prospective, randomized single-blind study of the anesthetic efficacy of the inferior alveolar nerve block administered with a peripheral nerve stimulator. J Enod 2010; 36:429-433.

13. Berns JM, Sandove MS. Mandibular block injection: a method of study using an injected radio opaque material. J Am Dent Assoc 1962; 65:735-745.

14. Kilic C, Kamburoğlu K, Ozen T, Balcioglu HA, Kurt B, Kutoglu Tet al. The position of the mandibular canal and histologic feature of the inferior alveolar nerve. Clin Anat 2010; 23:34-42.

15. Manikandhan R, Mathew PC, Naveenkumar J, Anantanarayanan P. A rare variation in the course of the inferior alveolar nerve. Int J Oral Maxillofac Surg 2010; 39:185-187.

16. Atieh MA. Diagnostic accuracy of panoramic radiography in determining relationship between inferior alveolar nerve and mandibular third molar. J Oral Maxillofac Surg 2010; 68:74-82.

17. Frommer J, Mele FA, Monroe CW. The possible role of the mylohyoid nerve in mandibular posterior tooth sensation. J Am Den Assoc 1972; 85:113-117.

18. Casey DM. Accessory mandibular canals. New York State Dent J 1978; 44:232-233.

19. Wilson S, Johns P, Fuller PM. The inferior alveolar and mylohyoid nerves: An Anatomic study and relation ship to local anesthesia of the anterior mandibular teeth. J Am Den Assoc 1984; 108:350-240.

20. Madeira MC, Percinoto C, Silva MG. Clinical significance of supplementary innervation of the lower incisor teeth: a dissection study of the mylohyoid nerve. Oral Surg Oral Med Oral Pathol 1978; 46:608-614.

21. Fazan VPS, Rodrigues OA, Matamata F. Communication between the mylohyoid and lingual nerves: clinical Implications. Int. J. Morphol 2007;25: 561-564.

22. Grover PS, Lorton L. Bifid Mandibular nerve as a possible cause of inadequate anesthesia in the mandible. J Oral Maxillofac surg 1983; 41:177-179.

23. Langlais RP, Broadus R, Glass BJ. Bifid mandibular canals in Radiographs. J Am Dent assoc 1985; 110:923-926.

24. Kuribayashi A, Watanabe H, Imaizumi A, Tantanapornkul W, Katakami K, Kurabayashi T. Bifid mandibular canals: cone beam computed tomography evaluation. Dentomaxillofac Radiol 2010; 39:235-239.

25. Auluck A, Pai KM. Trifid mandibular nerve canal. Dentomaxillofac Radiol 2005;34: 259.

26. Carter RB, Keen EN. The intra mandibular course of the inferior alveolar nerve. J Anat 1971; 108:433-440.

27. Sawyer DR, Kiely ML. Retromolar foramen: a mandibular variant important to dentistry. Ann Dent 1991; 50:16-18.

28. Rood JP. The nerve supply of the mandibular incisor region. Br Dent J 1977; 143:227-230.

29. Zmener O. Mental nerve parasthesia associated with an adhesive resin restoration: A case report. J Endod 2004; 30:117-119.

30. Bergman RA, Afifi AK, Miyauchi R Illustrated Encyclopedia of Human Anatomic Variation.(wwwdocument)URLhttp://www.anatomyatlases.org/AnatomicVariants/MuscularSystem/Text/F/17Flexor.shtml [Accessed on January 29, 2011].

31. Murakami G, Ohtsuka K, Sato I, Moriyama H, Shimada K, Tomita H (1994) The superior alveolar nerves: their topographical relationship and distribution to the maxillary sinus in human adults. Okajimas Folia Anat Jpn 1994; 70:319-328. 
32. Williams PL, Bannister LH, Berry MM et al. Respiratory System. In: Gray's Anatomy. The Anatomical Basis of Medicine and Surgery, 38th edition, Churchhil Livingstone London;1995; 1628-1682.

33. Selden HS, August DS. Maxillary sinus involvement-An endodontic complication- Report of a case. Oral Surg Oral Med Oral Pathol 1970;30:117-122.

34. Minkow B, Laufer D, Gutman D. Accute maxillary sinusitis caused by a gutta percha point. Refuat Hapeh Vehashinayim. 1977; 26:33-34.

35. Nair UP, Nair MK. Maxillary sinusitis of odontogenic origin: cone-beam volumetric computerized tomography-aided diagnosis. Oral Surg Oral Med Oral Pathol Oral Radiol Endod 2010; 110(6): e53-57.

36. Hauman $\mathrm{CH}$, Chandler NP, Tong DC. Endodontic implication of the maxillary sinus: A Review. Int Endodon J 2002; 35:127-141.

37. Ehrich DG, Brain JD Jr, Walker WA. Sodium hypochlorite accident: Inadvertent injection into the maxillary sinus. J Endod 1993; 19:180-182.

38. Fava LRG. Calcium hydroxide paste in the maxillary sinus: a case report. Int Endodon J 1993; 26:306310.

39. Kawahara H, Yamagami A,Nakumura M Jr. Biological testing of dental materials by means of tissue culture. International dental journal 1968;18:443-467.

40. Haanaes HR, Hepse HU, Stenvik A, Stermer Beyer-olsen EM, Bjornland T. Effect of calcium hydroxide implantation in maxillary sinus in macaques. Endodontics and Dental traumatology 1987; 3:229-232.

41. Orlay HG. Overfilling in root canal treatment. Two accidents with N2. Br Dent J 1966; 120:376.

42. Nimigean VR, Nimigean V, Maru N, Andressakis D, Balatsouras DG, Danielidis V. The maxillary sinus and its endodontic implications: clinical study and review. B-ENT 2006; 2:167-175.

43. Sjogren U, Sundqvist G, Nair PN. Tissue reaction to gutta-percha particles of varying sizes when implanted subcutaneously in guinea pigs. European J of oral science 1995;103:313-321.

44. Kaplowitz GJ. Penetration of the maxillary sinus by over extended gutta percha cones- Report of two cases. Clinical Preventive Dentistry 1985; 7:28-30.

45. Liston PN, Walters RF. Foreign bodies in the maxillary antrum : A case report. Aust Dental J 2002; 47:344-346.

46. Seltzer S, Green DB, Weiner N, DeRenzis F. A scanning electron microscope examination of silver cones removed from endodontically treated teeth. Oral Surg Oral Med Oral Pathol 1972; 33:589-605.

47. Benenati FW. Resection of a sapphire endodontic stabilizer due to perforation of maxillary sinus: a report of case. J Endod 1989;15:608-610.

48. Bauer W H. Maxillary sinusitis of dental origin. American journal of orthodontics and oral surg 1943; 29:133-151.
49. Schwartz S, Cohen S. The difficult differential diagnosis. Dental clinics of north America 1992; 36:279292.

50. Schow SR. Odontogenic diseases of the maxillary sinus. In: Peterson LJ, Ellis E, Hupp JR, Tucker MR, editors. Contemporary Oral and Maxillofacial Surgery, 2nd edn. St Louis, USA: Mosby, Year Book, Inc; 2004: $465-482$.

51. Pinheiro AD, Facer GW, Kern EB. Sinusitis: current concepts and management. In: Bailey BJ, Calhoun KH, editors. Head and Neck Surgery-Otolaryngology. Vol. 1. 2nd ed. Philadelphia, New York: LippincottRaven; 1998; 441-445.

52. Raddman WP. Maxillary sinus revisited by an endodontist. J Endod 1983; 9:382-383.

53. Clayman GL, Adams GL, Paugh DR, Koopman CF Jr. Intracranial complications of paranasal sinusitis: a combined institutional review. Laryngoscope 1991; 101:234-239.

54. Wacym PA, Canalis RF, Feverman T. Subdural empyema of otorhinological origin. J Laryngol Otol 1990; 104:118-122.

55. Beck-Mannagetta J, Necek D. Radiologic findings in aspergillosis of the maxillary sinus. Oral Surg Oral Med Oral Pathol 1989; 62:345-349.

56. Legent F, Billet J, Beauvillian C, Bonnet J, Miegeville $\mathrm{M}$. The role of dental fillings in the development of Aspergillus sinusitis: A report of 85 cases. Arch Otorhinolaryngol $1989 ; 246: 318-320$.

57. Freedman A, Horrowitz I. Complications after apicoectomy in maxillary premolar and molar teeth. Int J Oral Maxillofacial Surg 1999;28:192-194.

58. Watzek G, Bernhart T, Ulm C. Complications of sinus perforations and their management in endodontics. Dental Clin N Am 1997; 41:563-583.

59. Eberhardt JA, Torabinejad M, Christianson EL. A computer tomographic study of the distance between the maxillary sinus floor and the apices of the maxillary posterior teeth. Oral Surg Oral Med Oral Pathol Endod 1992; 73:345-346.

60. Johnson BR, Witherspoon DE. In: Cohen S, Hargreaves KM, ed. Pathways of the pulp, Periradicular Surgery, 9th ed. Elsevier St Louis, Missouri. USA 2007: 724-785.

61. Barnes IB. Surgical Endodontics. 2nd edn, London, UK: Wright; 1991:561.

62. Jerome CE, Hill AV. Preventing root tip loss in the maxillary sinus during endodontic surgery. J Endod $1995 ; 21: 422-444$.

63. Wallace JA. Transantral endodontic surgery. Oral Surg Oral Med Oral Pathol Endod 1996; 82:80-84.

64. Wright EF. Pulpalgia contributing to temperomandibular disorder like pain:a literature review and case report. J Am Dent Assoc 2008; 39:436-440.

65. Falace DA, Reid K, Rayens MK. The influence of deep (odontogenic) pain intensity, quality and duration on the incidence and characteristics of referred orofacial pain .J Orofac Pain 1996; 10:232-239. 
66. Vecchiet L, Viamberardino MA. Referred pain:Clinical significance, pathophysiology and treatment. Phys Med Rehabil Clin N Am 1997; 8:119-136.

67. Okeson JP. Bell's Orofacial Pains: The Clinical Management of Orofacial Pain. 6th ed. Carol Stream, Ill Quintessence; 2005: 72, 261-273.

68. Xie YF, Zhang S, Chiang CY, Hu JW, Dostrovsky JO, Sessle BJ. Involvement of glia in central sen- sitization in trigeminal subnucleus caudalis (medullary dorsal horn). Brain Behav Immun 2007; 21:634-641.

69. Sreenby LM. Xerostomia: diagnosis, management and clinical complications. In: Edgar WM, O'Mullane DM, eds. Saliva and oral health. 2nd edn. London: British Dental Association; 1996; 43-66. 